\title{
Optimasi Ekonomi dan Emisi Pembangkit Listrik di Kalimantan menggunakan Dragonfly Algoritmh
}

\author{
BAYU SETYO WIBOWO, SUSATYO HANDOKO, HERMAWAN
}

Universitas Diponegoro Semarang, Indonesia

Email: setyobayu83@gmail.com

Received 23 Februari 2021 | Revised 28 Maret 2021 | Accepted 2 April 2021

\section{ABSTRAK}

Kebutuhan listrik di Kalimantan Selatan dan Tengah menjadi semakin bertambah dikarenakan meningkatnya jumlah penduduk dan ekonomi serta mahalnya biaya pembangkitan listrik. Tujuan penelitian ialah meminimalkan biaya pembangkitan termal dan memecahkan permasalahan ekonomi dan emisi. Penelitian menggunakan metode Dragonfly algortihm yang mengkaji tentang optimasi ekonomi dan emisi pada PLTU Asam-asam, Pulang Pisau dan PLTA Riam Kanan dengan membuat program dengan menginputkan Cost Function dan Emission Function. Didapatkan rata-rata biaya pembangkitan dan emisi dari tanggal 1 - 4 September 2020 yaitu pada kasus 1 biaya pembangkit sebesar Rp 335.855.120 dan emisi sebesar 628,6 ton, pada kasus 2 biaya pembangkit sebesar $R p$ 251.891.340 dan emisi sebesar 943 ton, pada kasus 3 biaya pembangkit sebesar Rp 167.935.460 dan emisi sebesar 1257,3ton. Faktor pembobotan akan mempengaruhi biaya pembangkitan dan emisi yang dihasilkan.

Kata kunci: Pembangkit Listrik, Dragonfly algortihm, Faktor Pembobotan

\begin{abstract}
The demand for electricity in South and Central Kalimantan is increasing due to the increasing population and economy as well as the high cost of generating electricity. The research objective is to minimize the cost of thermal generation and solve economic and emission problems. This research uses the Dragonfly algorithm method which examines the economic optimization and emissions at PLTU Asam-Asam, Pulang Pisau and PLTA Riam Kanan by making a program by inputting Cost Function and Emission Function. Obtained the average cost of generation and emissions from September 1 - 4 2020, namely in case 1 the generator cost is IDR 335,855,120 and the emission is 628.6 tons, in case 2 the generator cost is IDR 251,891,340 and the emission is 943 tons, in case 3 the cost of the generator is Rp. 167,935,460 and the emission is 1257.3 tonnes. The weighting factor will affect the cost of generation and the resulting emissions.
\end{abstract}

Keywords: Power Plant, Dragonfly algorithm, Weighting Factor 


\section{PENDAHULUAN}

Energi merupakan salah satu elemen dasar pendukung pertumbuhan ekonomi. Kebutuhan akan lebih banyak energi meningkatkan gas rumah kaca, yang menyebabkan perubahan iklim. Energi listrik ialah salah satu energi yang paling vital bagi pertumbuhan ekonomi (Sutanto, dkk, 2015). Kebutuhan listrik di Kalimantan Selatan dan Kalimantan Tengah menjadi semakin bertambah dikarenakan meningkatnya jumlah penduduk dan ekonomi. Sistem kelistrikan di provinsi Kalimantan bagian selatan dan bagian tengah disuplai terutama oleh sistem Barito. Sistem Barito ialah sistem sambungan listrik di Kalimantan bagian selatan dan bagian tengah dengan jaringan transmisi 70 kiloVolt dan 150 kiloVolt (Widyastuti, dkk, 2015).

Provinsi Kalimantan Selatan pada tahun 2018 mengkonsumsi 4.058 GWh energi listrik dengan komposisi konsumsi per sektor pemakai didominasi oleh sektor rumah tangga kurang lebih $2.046 \mathrm{GWh}$ (50\%), industri kurang lebih $1.172 \mathrm{GWh}(29 \%)$, sektor bisnis kurang lebih 564 GWh (14\%), dan publik kurang lebih 275 GWh (7\%) (PLN, 2015). Hal tersebut mewajibkan PLN (Perusahaan Listrik Negara) untuk menjaga kestabilan penyaluran daya listrik pada sistem kelistrikan secara aman dan efisien serta memaksimalkan pembebanan dasar dengan cara melakukan optimasi. Saat ini komponen biaya produksi terbesar adalah biaya bahan bakar, dan pada saat ini konsumsi energi listrik telah mengalami pertumbuhan pesat. PLN juga melanjutkan upayanya untuk mengganti sumber energi yang hemat biaya dan ekonomis melalui optimasi (Abdullah, dkk, 2019).

Pada sistem tenaga listrik yang terhubung dalam suatu jaringan interkoneksi, unit pembangkit tidak dalam lingkungan yang sama dengan beban. Selain itu, biaya operasional pembangkit perunit berbeda. Selama operasi normal, daya sistem pembangkit harus lebih besar dari total kebutuhan beban dan rugi daya sistem (Giovanni, 2016). Suatu sistem tenaga listrik yang handal harus memperhatikan sektor ekonomi dan kehandalannya, tetapi juga membutuhkan sistem yang memperhatikan kerusakan lingkungan (Sutanto, dkk, 2015). Optimasi pembangkitan hidrotermal adalah cara yang cukup ekonomis dalam sistem tenaga listrik untuk memenuhi kebutuhan pelanggan. Biaya total operasi lebih banyak ialah dari biaya pembangkitan termal selama waktu optimisasi. Unit pembangkit hidro digunakan untuk memikul beban dasar dikarenakan biaya operasi yang efisien, Selanjutnya unit pembangkit termal dioperasikan untuk memenuhi kebutuhan beban yang tersisa dengan biaya operasi yang tidak efisien (Rahmat, dkk, 2014). Pembangkit listrik tenaga termal adalah sumber utama sulfur dioksida (SO2), nitrogen oksida (NOx) dan karbon dioksida (CO2) yang mengakibatkan polusi pada atmosfer (Nguyen \& Vo, 2018). Apalagi efisiensi energi dan jumlah emisi yang dilepaskan ke udara dari pembangkit listrik termal memiliki intelerasi yang berarti jika efisiensi ditingkatkan menghasilkan emisi polusi yang akan berkurang (Glotić \& Zamuda, 2015). Terdapat beberapa metode yang dipakai untuk mencari solusi permasalah optimasi pembangkit hidro termal, metode optimasi tersebut digolongkan menjadi dua yaitu metode deterministik dan metode kecerdasan buatan.

Pada penelitian ini penulis akan menerapkan Dragonfly Algorithm karena merupakan algoritma yang tergolong baru dan belum banyak yang membahas tentang Optimasi ekonomi dan emisi. Berdasarkan teori dari Dragonfly Algorithm dimulai secara statis sebagai titik awal dan perilaku kawanan capung yang energik. Perilaku yang berkerumun ini terlihat seperti perumpamaan di kedua tahap kunci dalam optimasi melalui meta algoritma heuristik, yaitu, investigasi dan pemanfaatan (Shilaja \& Arunprasath, 2019). Dalam Referensi penelitian metode optimasi dalam hibrida meta-heuristic, DA (Dragonfly Algorithm) untuk menangani masalah Optimation power flow. Algoritma yang disebutkan diterapkan untuk 
mendapatkan kontrol sistem tenaga variabel nilai optimal dan untuk memperbaiki masalah OPF. Hal itu dapat meminimalkan kehilangan daya, penyimpangan dalam profil tegangan dan bahan bakar kontrol biaya yang merupakan tujuan utama masalah OPF (Shilaja \& Arunprasath, 2019). Akan tetapi belum ada penelitian tentang optimasi ekonomi dan emisi menggunakan Dragonfly algorithm. Penelitian terdahulu sudah pernah menggunakan Dragonfly algorithm untuk meminimalkan kesalahan sistem berdasarkan fungsi obyektif untuk mengelola aliran daya (Sureshkumar \& Ponnusamy, 2019). Metode Dragonfly algorithm untuk optimasi memperkirakan prediksi jangka pendek model tenaga angin ( $\mathbf{L i}$, dkk, 2020). Selanjutnya Dragonfly algorithm untuk mengoptimasi model penjadwalan Wind-Solar-Hydro power ( Li, dkk, 2019).

Pada penelitian ini penulis akan menerapkan dengan metode kecerdasaan buatan Dragonfly Algorithm sebagai Optimasi yang digunakan untuk pengambilan keputusan. Keunggulan metode Dragonfly Algorithm yang diusulkan ialah menunjukkan hasil lebih baik untuk kinerja prediksi dibandingkan dengan metode yang lain (Li, dkk, 2020). Tujuan penelitian ialah meminimalkan biaya pembangkitan termal dan memecahkan permasalahan ekonomi dan emisi.

\section{METODE PENELITIAN}

Penelitian ini menggunakan metode seperti diagram alir yang ditunjukkan pada Gambar 1. Pertama mengkaji tentang optimasi ekonomi dan emisi pada PLTU Asam-asam, Pulang Pisau dan PLTA Riam Kanan selanjutnya membuat program dengan software menggunakan metode dragonfly algorithm dengan menginputkan Cost Function dan Emission Function. Verifikasi dilakukan dengan pengujian ekonomi dan emisi dengan Faktor Pembobotan. Pada bagian terakir membuat kesimpulan mengenai masalah yang ada.

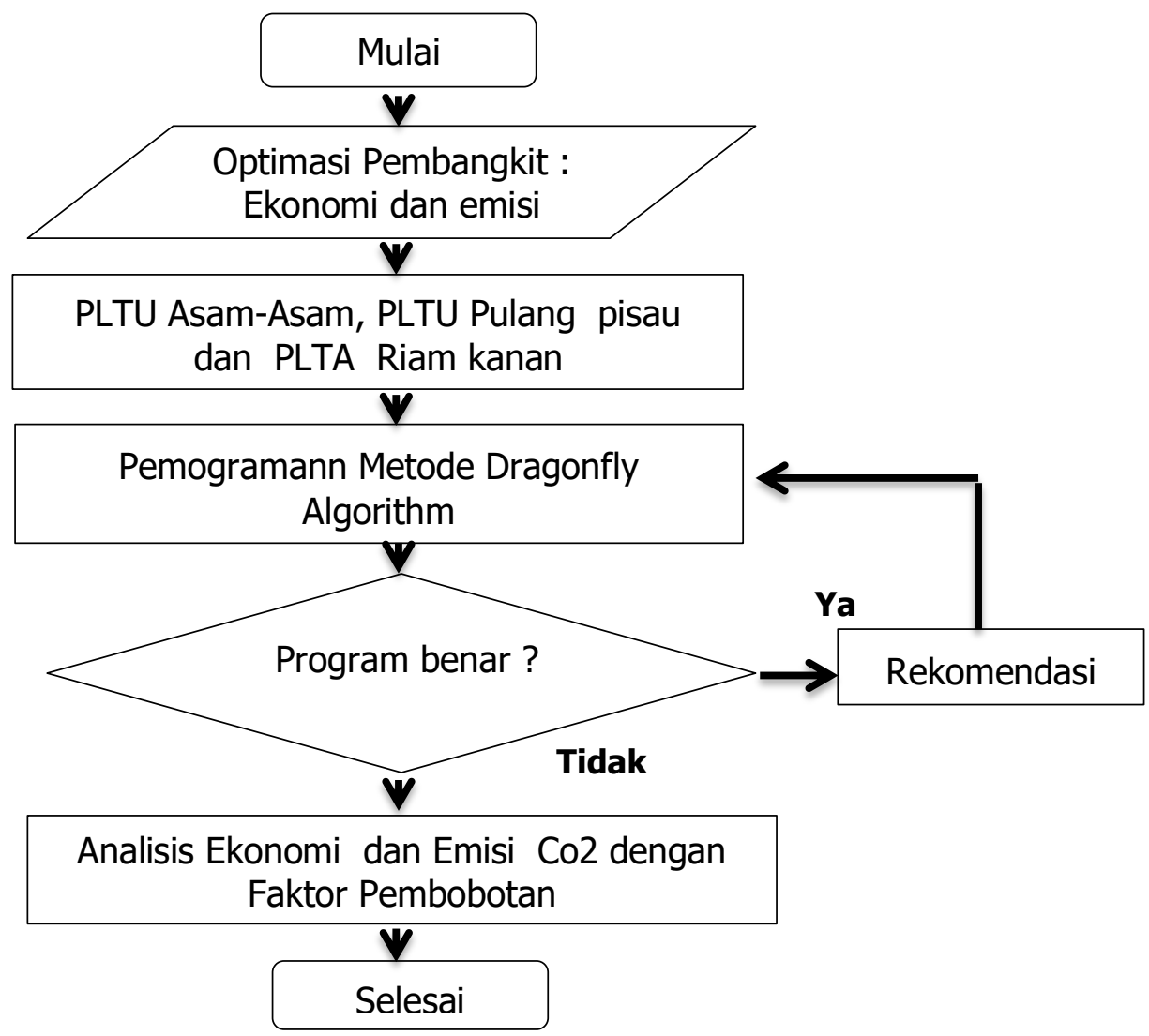

Gambar 1. Diagram alir metode penelitian 


\subsection{Optimasi Pembangkit Listrik}

Pengoperasian sistem tenaga listik penting untuk mencapai operasi distribusi beban generator yang maksimal. Dalam proses pengkoordinasian daya yang dihasilkan oleh unit pembangkit pusat diperlukan penyelarasan agar diperoleh biaya konsumsi bahan bakar yang murah (Pratama, dkk, 2017).

\subsection{Pengiriman Ekonomis (Economic Dispatch)}

Pengiriman ekonomis ialah salah satu cara untuk menentukan besarnya daya yang harus disuplai dari masing-masing unit pembangkit untuk memenuhi beban tertentu dengan membagi beban pada unit pembangkit dalam sistem secara maksimal dengan tujuan untuk mengefisienkan biaya konsumsi bahan bakar pada pembangkitan (Prayogo, dkk, 2016).

\subsection{Combined Economic and Emission Dispatch}

Pengiriman ekonomi dan pengiriman emisi adalah optimalisasi dengan tujuan masalah emisi yang terabaikan dalam pengiriman ekonomi dan tujuan biaya bahan bakar tidak dipertimbangkan dalam masalah pengiriman emisi (Nguyen \& Vo, 2018).

$$
\text { Min Objective }=w 1 \times F 1\left(P_{\text {si,m }}\right)+w 2 \times \operatorname{PRm} \times F 2\left(P_{\text {si, } m}\right)
$$

$\begin{array}{ll}\text { Keterangan } & \text { : } \\ \text { w1 } & \text { : Faktor bobot dengan tujuan biaya bahan bakar } \\ \text { w2 } & \text { : Faktor bobot dengan tujuan emisi } \\ \text { F1 } & \text { : Tujuan biaya bahan bakar } \\ \text { F2 } & \text { : Tujuan Emisi } \\ \text { Psi,m } & \text { : Keluaran daya unit termal } \\ \text { PRm } & \text { : Faktor pinalti harga }\end{array}$

\subsection{Karakteristik Unit Pembangkit}

Jenis - jenis tipe pembangkit dalam sistem ada tiga yaitu pembangkitan untuk beban dasar, untuk pembangkitan beban menengah dan untuk pembangkit beban puncak (Bobby Prayogo, dkk, 2016).

Karakteristik imasukan-keluaran pembangkit termal dalam penelitian ini pembangkit listrik tenaga uap berbentuk British thermal unit per unit pembangkit. Biaya produksi adalah perkalian antara biaya (Rp) kalori yang terkandung dalam terdapat pada bahan bakar, dalam hal ini batu bara, dengan kebutuhan kalori per jam generator (Btu / jam). Tenaga yang dihasilkan disimpan sebagai PG (Saadat, 2019). Karakteristik tersebut menghasilkan hubungan antara masukan generator berfungsi menjadi keluaran generator. Persamaan karakteristik masukan-keluaran pembangkit tenaga listrik menjelaskan hubungan antara jumlah sumber energy (batubara) yang dibutuhkan untuk menghasilkan tenaga tertentu pada suatu pembangkit dengan pendekatan fungsi binomial yaitu (Jadoun, dkk, 2015):

$$
(\mathrm{F})=\mathrm{x} P^{2}+\mathrm{y} P+\mathrm{z}
$$


Keterangan:

$\begin{array}{ll}\mathrm{F} & \text { : Biaya bahan bakar (Batu bara) } \\ \mathrm{P} & \text { : Hasil daya pembangkit (MW) } \\ \mathrm{X}, \mathrm{y}, \mathrm{z} & \text { : Konstanta }\end{array}$

\subsection{Dragonfly Algoritmh}

Dragonfly Algorithm ialah salah satu algoritma kecerdasaan buatan yang berfungsi sebagai optimasi yang digunakan untuk pengambilan keputusan. Dragonfly algorithm dimulai dengan statis sebagai titik awal dan kerumunan energik perilaku capung. Kedua perilaku mengerumuni itu terlihat serupa di kedua tahap utama dalam pengoptimalan melalui meta algoritma heuristik, yaitu investigasi dan pemanfaatan (Shilaja \& Arunprasath, 2019).

Perilaku ini diwakili oleh model matematika berikut menggunakan Persamaan (3) sampai Persamaan (7).

1. Perilaku Pemisahan:

$$
S_{i}=\sum_{j=1}^{N} X-X
$$

dimana $\mathrm{j}=1 ; 2 ; \ldots ; \mathrm{N}, \mathrm{i}=1 ; 2 ; \ldots ; \mathrm{Np}, \mathrm{N}$ ialah jumlah kelompok individu capung, dan $\mathrm{Np}$ adalah jumlah populasi capung. $\mathbf{X}$ menunjukkan posisi individu capung saat ini, $\mathbf{X j}$ adalah posisi $\mathrm{j}$-th individu kelompok

2. Perilaku menjaga penerbangan terkoordinasi dengan kelompok capung:

$$
A_{i}=\frac{\sum_{j=1}^{N} V_{j}}{N}
$$

dimana Vj melambangkan kecepatan kelompok ke-j individu capung

3. Perilaku mendekat satu sama lain untuk setiap individu (Kohesi):

$$
C_{i}=\frac{\sum_{j=1}^{N} X_{j}}{N}-X
$$

4. Perilaku mencari makan:

$$
F_{i}=X^{+}-X
$$

di mana $\mathrm{X}+$ mewakili posisi individu capung saat ini dengan nilai kebugaran optimal.

5. Perilaku menghindari musuh:

$$
E_{i}=X+X^{-}
$$

di mana $X$ - mewakili posisi individu capung saat ini dengan nilai kebugaran terburuk. 


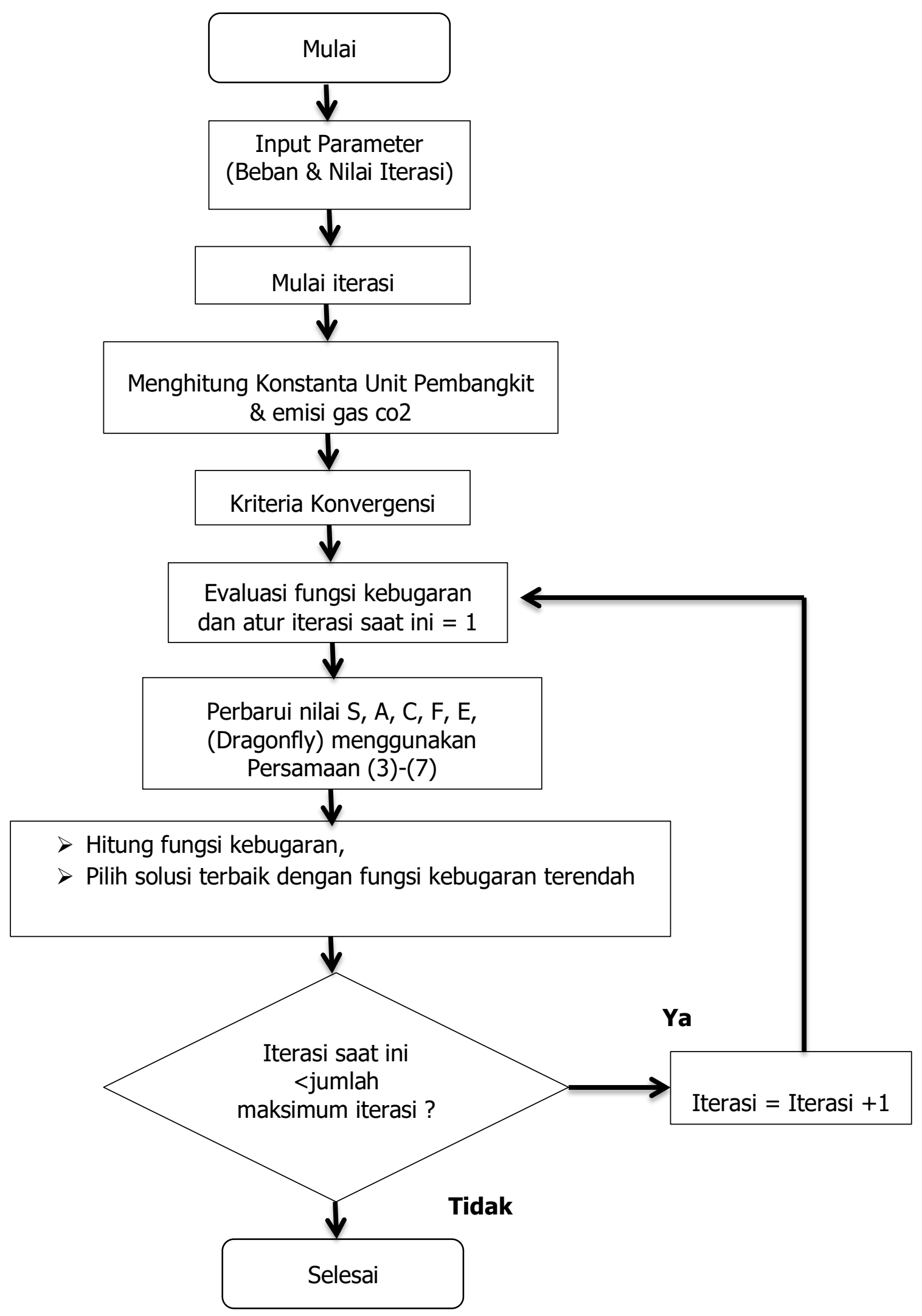

Gambar 2. Diagram alir dragonfly algorithm 
Tahapan dalam Diagram alir pada Gambar 2 meliputi :

1. Mulai ialah suatu proses untuk mengawali suatu sistem optimasi ekonomi dan emisi.

2. Input Paramater ialah suatu proses penginputan data untuk input program yang akan dioptimasi berupa nilai iterasi, beban (MW) dari pembangkit termal dan pembangkit hidro serta Agent yang ditentukan.

3. Iterasi didapat dengan menggunakan lambda pada pembangkit termal (PLTU).

4. Menghitung Konstanta dengan menggunakan regresi polynomial orde 2 untuk Cost Function dan Emission Function .

5. Kriteria Konvergensi ialah suatu kriteria untuk melakukan penggecekan perhitungan atau program tersebut.

6. Evaluasi fungsi kebugaran ialah suatu proses fungsi dari dragonfly algorithm.

7. Perbaharui nilai dari persamaan dragonfly algorithm dapat dilihat pada Persamaan (3)-(7) yang diperlukan untuk melakukan optimasi ekonomi dan emisi.

8. Proses Perhitungan dan pemilihan solusi dari dragonfly Algorithm untuk optimasi ekonomi dan emisi pembangkit termal dan pembangkit hidro. Proses ini akan berlangsung secara terus menerus dan akan berhenti jika iterasi maksimum tercapai,

9. Selesai ialah ketika iterasi maksimum tercapai, maka daya output pembangkit, biaya biaya pembangkitan termurah dan emisi akan ditampilkan.

\section{HASIL DAN PEMBAHASAN}

Dalam penelitian ini akan dilakukan proses pengujian metode yang diusulkan. Sebelum diterapkan pada sistem 150 kilovolt Kalimantan Selatan dan Kalimantan Tengah, terlebih dahulu akan dilakukan pengujian terhadap metode dengan cara mensimulasikan menggunakan sistem IEEE 26 bus selanjutnya pengujian dilakukan tanpa mempertimbangkan emisi dan dengan mempertimbangkan emisi. Tampilan pada GIU software dapat dilihat pada Gambar 3 dan Gambar 4.

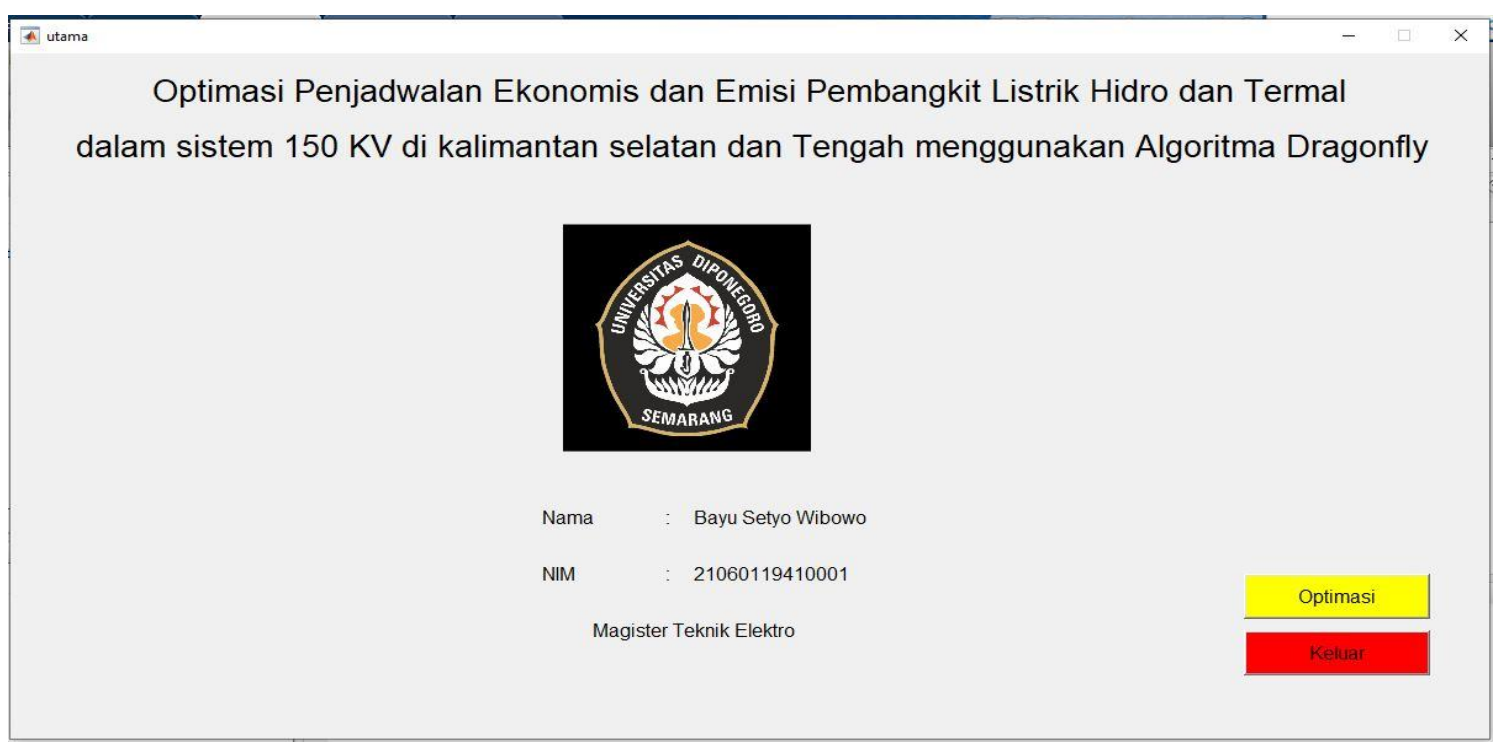

\section{Gambar 3. Fitur pada giu awal}

Pada Gambar 3 Fitur giu awal terdapat judul, logo universitas dan identitas dari peneliti serta terdapat icon optimasi yang berfungsi sebagai tombol untuk masuk ke GIU utama dan terdapat icon keluar untuk mengakhiri atau keluar dari software. 


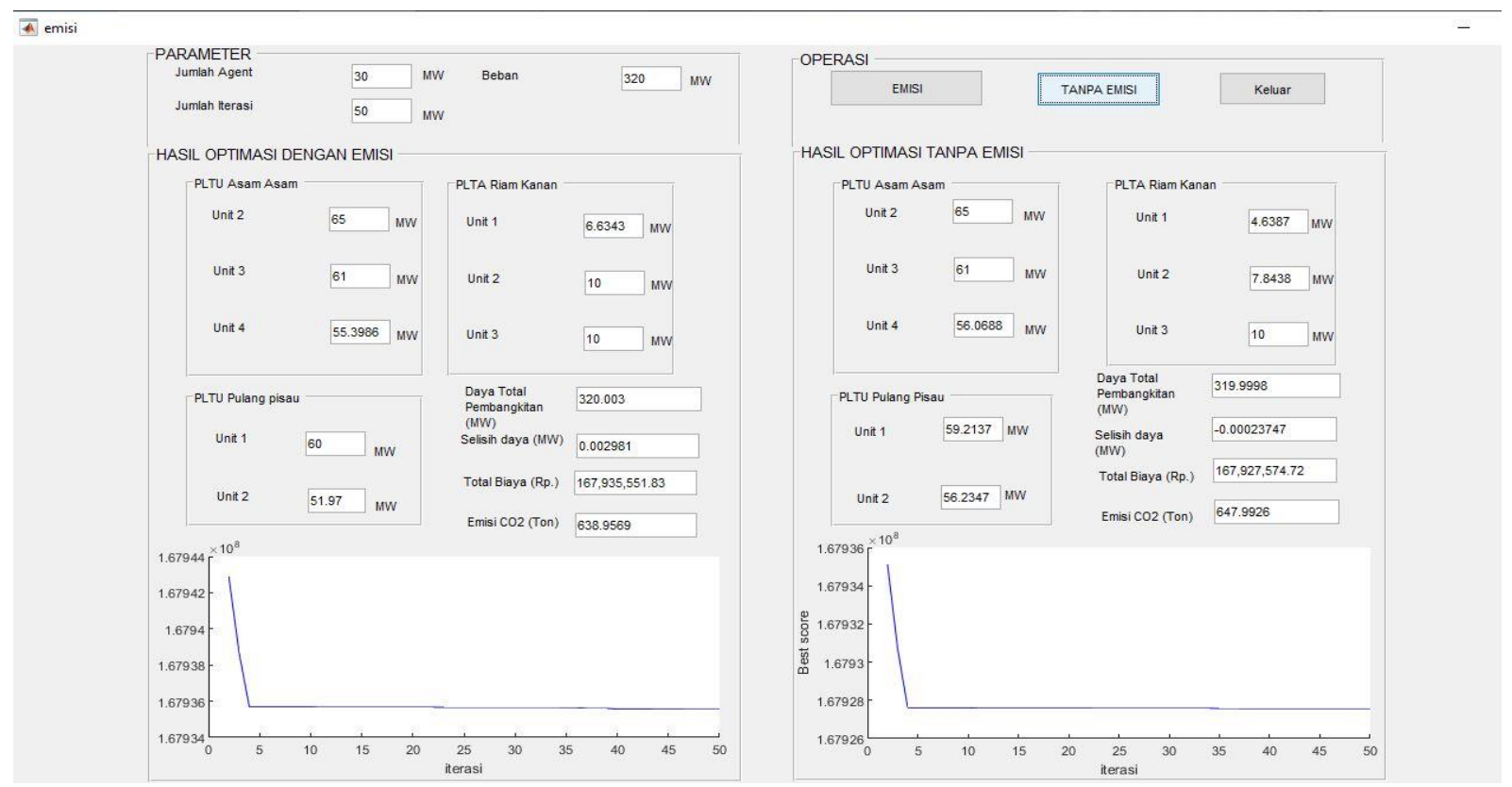

Gambar 4. Fitur pada giu dragonfly algorithm

Pada Gambar 4 Fitur GIU tersebut terdapat :

1. Icon Parameter Jumlah Agent, Jumlah Iterasi dan Beban berfungsi sebagai inputan untuk melakukan optimasi,

2. Terdapat 2 hasil optimasi dengan emisi dan optimasi tanpa emisi yang masing-masing menjelaskan Icon Hasil Pada Giu tersebut ialah nilai Optimasi daya dari PLTU Asamasam, PLTU Pulang pisau dan PLTA Riam Kanan menggunakan Dragonfly Algortihm,

3. Icon Daya Total Pembangkit (MW) ialah Nilai Optimasi dari daya yg ditentukan oleh Beban pada Parameter dan total dari nilai Optimasi daya dari masing-masing PLTU Asam-asam, PLTU Pulang pisau dan PLTA Riam Kanan,

4. Icon Selisih Daya (MW) ialah hasil dari selisih inputan beban (MW) dengan hasil daya total pembangkit (MW)

5. Icon Total Biaya (Rp) ialah jumlah biaya pembangkitan (Rp) dari PLTU Asam-asam, PLTU Pulang pisau dan PLTA Riam Kanan menggunakan Dragonfly Algortihm,

6. Icon Emisi $\mathrm{CO}^{2}$ ialah hasil emisi dari PLTU Asam-asam, PLTU Pulang pisau dan PLTA Riam Kanan menggunakan Dragonfly Algortihm,

7. Grafik ialah gambar yang menunjukan hubungan nilai iterasi terhadap Total biaya (Rp)

\subsection{Pengujian Metode Dragonfly Algorithm}

Terlebih dahulu metode akan dilakukan pengujian sebelum diaplikasikan pada sistem $150 \mathrm{kV}$ untuk Kalimantan Selatan dan Kalimantan Tengah, mula-mula dilakukan pengujian metode yang ingin digunakan. Pertama akan dilakukan pengujian dengan standard Ieee sistem 26 bus selanjutnya dilakukan pengujian memperhitungkan emisi dengan menggunakan 3 Unit pembangkit dari PLTU Asam-asam, 2 Unit PLTU Pulang pisau dan 3 Unit PLTA Riam kanan.

\section{Pengujian Dengan Standard IEEE}

Dalam Sistem bus IEEE 26 pembangkit termal berjumlah 5 unit terdiri dari 3 Unit pembangkit PLTU Asam-asam, 2 Unit PLTU Pulang pisau. Berikut ialah data yang akan menjadi masukan pada program utama. Dapat dilihat pada Tabel 1 sampai dengan Tabel 3. 
Optimasi Ekonomi dan Emisi Pembangkit Listrik di Kalimantan Selatan dan Kalimantan Tengah menggunakan Dragonfly Algoritmh

Tabel 1. Data fungsi biaya dan daya pembangkit sistem ieee 26 bus

\begin{tabular}{|c|c|c|c|c|c|}
\hline \multirow{2}{*}{ Unit } & \multicolumn{2}{|c|}{ Cost Function } & \multirow{2}{\text{Pmin}}{} & Pmax \\
\cline { 2 - 5 } & a & b & c & (MW) & (MW) \\
\hline 1 & 0,00375 & 2 & 0 & 50 & 200 \\
\hline 2 & 0,0175 & 1,7 & 0 & 20 & 80 \\
\hline 3 & 0,0625 & 1 & 0 & 15 & 50 \\
\hline 4 & 0,00834 & 3,25 & 0 & 10 & 35 \\
\hline 5 & 0,025 & 3 & 0 & 10 & 30 \\
\hline
\end{tabular}

Pada Tabel 1 ialah data Cost Function dari 5 Unit pembangkit termal sistem ieee 26 bus berupa constanta a, b, c dan Pmin (MW) serta Pmax (MW) yang akan diinputkan pada software

Tabel 2. Data fungsi emisi tiap unit pembangkit sistem ieee 26 bus

\begin{tabular}{|c|c|c|c|}
\hline \multirow{2}{*}{ Unit } & \multicolumn{3}{|c|}{ Emission Function } \\
\cline { 2 - 4 } & a & b & c \\
\hline 1 & 0,0126 & $-0,9$ & 22,983 \\
\hline 2 & 0,02 & $-0,1$ & 25,313 \\
\hline 3 & 0,027 & $-0,01$ & 25,505 \\
\hline 4 & 0,0291 & $-0,005$ & 24,9 \\
\hline 5 & 0,029 & $-0,004$ & 24,7 \\
\hline
\end{tabular}

Pada Tabel 2 ialah data Emission Function dari 5 Unit pembangkit termal sistem ieee 26 bus berupa constanta a, b, c yang akan diinputkan pada software.

Tabel 3. Hasil pengujian ieee 26 bus pada dragonfly algorithm

\begin{tabular}{|c|c|c|c|c|c|c|c|}
\hline \multicolumn{4}{|c|}{ Mempertimbangkan Emisi } & \multicolumn{4}{|c|}{ Tanpa Mempertimbangkan Emisi } \\
\hline Unit & $\begin{array}{l}\text { Daya } \\
\text { (MW) }\end{array}$ & Biaya & $\begin{array}{l}\text { Emisi } \\
\text { (Ton) }\end{array}$ & Unit & $\begin{array}{l}\text { Daya } \\
(\mathrm{MW})\end{array}$ & Biaya & $\begin{array}{l}\text { Emisi } \\
\text { (Ton) }\end{array}$ \\
\hline 1 & 176,16 & \multirow{5}{*}{ Rp.145.328.224 } & \multirow{5}{*}{694,1337} & 1 & 175,1294 & \multirow{5}{*}{ Rp.145.318.960 } & \multirow{5}{*}{696,6862} \\
\hline 2 & 68,64 & & & 2 & 73,1651 & & \\
\hline 3 & 36,68 & & & 3 & 16,05 & & \\
\hline 4 & 23,1 & & & 4 & 28,99 & & \\
\hline 5 & 14,09 & & & 5 & 26,5344 & & \\
\hline
\end{tabular}

Pada Tabel 3 hasil pengujian IEEE 26 Bus pada Dragonfly Algorithm pada beban 320 MW dengan mempertimbangkan emisi didapatkan biaya pembangkit sebesar Rp145.328.224 dan emisi sebesar 694,1337 ton sedangkan tanpa mempertimbangkan emisi didapatkan biaya pembangkit sebesar Rp145.318.960 dan emisi sebesar 696,6862 ton. Pada pengujian dengan mempertimbangkan emisi didapatkan biaya pembangkitan lebih tinggi dari pengujian tanpa mempertimbangkan emisi namun hasil emisi (ton) menjadi lebih rendah dari pengujian tanpa mempertimbangkan emisi. 


\section{Pengujian Dengan Memperhitungkan Emisi}

Percobaan pengujian yang didapat dari software dilakukan sebanyak 5 kali dengan data beban dari pembangkit 3 Unit pembangkit PLTU Asam-asam, 2 Unit PLTU Pulang pisau dan 3 Unit PLTA Riam kanan. Faktor pembobotan $\mathrm{W} 1=0,5$ dan $\mathrm{W} 2=0,5$ dilakukan untuk pengujian yang dapat dilihat pada Tabel 4

Tabel 4. Biaya operasional pembangkitan dengan memperhitungkan emisi

\begin{tabular}{|c|c|c|c|}
\hline \multicolumn{4}{|c|}{ Biaya Pembangkitan Dengan Emisi } \\
\hline Tanggal & $\begin{array}{c}\text { Beban } \\
\text { (MW) }\end{array}$ & $\begin{array}{c}\text { Biaya } \\
\text { Pembangkitan }\end{array}$ & $\begin{array}{c}\text { Emisi } \\
\text { (Ton) }\end{array}$ \\
\hline 1 & 320 & Rp.167.935.457 & 631,618 \\
\hline 2 & 319 & $\mathrm{Rp} .167 .935 .429$ & 629,447 \\
\hline 3 & 311 & $\mathrm{Rp} .167 .935 .265$ & 617,065 \\
\hline 4 & 312 & $\mathrm{Rp} .167 .935 .259$ & 616,821 \\
\hline
\end{tabular}

Berdasarkan data pada Tabel 4 dengan 5 percobaan dengan metode Dragonfly algorithm didapatkan hasil biaya pembangkitan rata-rata sebesar Rp167.935.410 per hari dengan emisi sebesar 627,94 Ton per hari. Terlihat bahwa metode Dragonfly algorithm melakukan optimasi pada beban tertinggi pada tanggal 7 yaitu 332 MW dihasilkan biaya pembangkitan sebesar Rp 167.935.909 dan emisi sebesar 665,308 Ton.

\subsection{Hasil}

Hasil optimasi ekonomi dan emisi dengan metode Dragonfly Algoritmh pada system kelistrikan Kalimantan Selatan dan Kalimantan Tengah didapatkan melalui simulasi pada software dengan mengisi parameter Jumlah Agent, Jumlah Iterasi dan Beban simulasi akan dilakukan sebanyak 5 kasus percobaan selanjutnya diisikan Nilai pembobotan W1 dan W2 ditetapkan sebagai bobot dapat dilihat pada Tabel 5

\section{Tabel 5. Nilai pembobotan untuk simulasi}

\begin{tabular}{|c|c|c|}
\hline Kasus & W1 & W2 \\
\hline 1 & 1 & 0 \\
\hline 2 & 0,5 & 0,5 \\
\hline 3 & 0 & 1 \\
\hline
\end{tabular}

Dalam kasus pertama, prioritasnya hanya mengoptimalkan biaya pembangkit, bukan mengurangi nilai emisi. Kedua, optimasi direncanakan secara proporsional antara biaya pembangkit dan emisi. Pada kasus ketiga hanya memprioritaskan upaya pengurangan emisi dan bukan optimalisasi biaya pembangkitan. Hasil untuk biaya pembangkit dan emisi pada tanggal 1 September sampai dengan 4 September 2020 di sistem 150 kV Kalimantan Selatan dan Kalimantan Tengah dapat dilihat pada Tabel 6 sampai dengan Tabel 9.

Tabel 6. Total biaya dan emisi pada tanggal 1

\begin{tabular}{|c|c|c|c|}
\hline \multirow{2}{*}{ Kasus } & \multicolumn{3}{|c|}{ Tanggal 1} \\
\hline & & aya (Rp) & Emisi (ton) \\
\hline 1 & & 335.855 .126 & 633,3457 \\
\hline 2 & & 251.891 .345 & 950,01855 \\
\hline 3 & & 167.935 .457 & 1266,6914 \\
\hline
\end{tabular}


Pada Tabel 6 didapat biaya pembangkit dan emisi dengan beban pembangkit sebesar $320 \mathrm{~W}$ pada tanggal 1 September 2020. Pada kasus 1 didapatkan biaya pembangkit sebesar Rp 335.885.126 dan emisi sebesar 633,3 ton. Pada kasus 2 biaya pembangkit sebesar Rp 251.891.345 dan emisi sebesar 950,01 ton. Pada kasus 3 biaya pembangkit sebesar Rp 167.935.457 dan emisi sebesar 1266,7 ton.

Tabel 7. Total biaya dan emisi pada tanggal 2

\begin{tabular}{|c|c|c|}
\hline \multirow{2}{*}{ Kasus } & \multicolumn{2}{|c|}{ Tanggal 2} \\
\cline { 2 - 3 } & Biaya (Rp) & Emisi (ton) \\
\hline 1 & Rp335.855.120 & 629,4419 \\
\hline 2 & Rp251.891.340 & 944,16285 \\
\hline 3 & Rp167.935.458 & 1258,8838 \\
\hline
\end{tabular}

Pada Tabel 7 didapatkan biaya pemabangkit dan emisi pada tanggal 2 September 2020. Untuk beban 319 W, biaya pembangkitan adalah Rp 335.855.120 dengan emisi 629,4 ton. Pada Kasus 2, biaya pembangkitan listrik sebesar Rp 251.891.340 dengan emisi 944,16 ton. Pada kasus 3 biaya pembangkitan adalah Rp 167.935.458, dengan emisi 1258,8 ton.

Tabel 8. Total biaya dan emisi pada tanggal 3

\begin{tabular}{|c|c|c|c|}
\hline \multirow{2}{*}{ Kasus } & \multicolumn{3}{|c|}{ Tanggal 3} \\
\hline & & aya (Rp) & Emisi (ton) \\
\hline 1 & & 335.855 .102 & 616,6235 \\
\hline 2 & $\mathrm{Rp}$ & 251.891 .327 & 924,93525 \\
\hline 3 & & 167.935 .459 & 1233,247 \\
\hline
\end{tabular}

Tabel 8 menunjukkan biaya dan emisi generator dengan beban generator $311 \mathrm{~W}$ pada tanggal 3 September 2020. Pada kasus 1, biaya generator adalah Rp 335.885102 dan emisi 616,62 ton. Untuk kasus ke 2, biaya generatornya adalah Rp 251.891.327 dan emisinya 924,93 ton. Pada kasus ke 3, biaya generator adalah Rp 167.935.459 dan emisi 1.233,2 ton.

Tabel 9. Total biaya dan emisi pada tanggal 4

\begin{tabular}{|c|c|c|c|}
\hline \multirow{2}{*}{ Kasus } & \multicolumn{3}{|c|}{ Tanggal 4} \\
\hline & & aya (Rp) & Emisi (ton) \\
\hline 1 & & 335.855 .100 & 617,7919 \\
\hline 2 & $\mathrm{Rp}$ & 251.891 .325 & 926,68785 \\
\hline 3 & $\mathrm{Rp}$ & 167.935 .460 & 1235,5838 \\
\hline
\end{tabular}

Tabel 9 menunjukkan biaya pembangkitan dan emisi pada beban generator $312 \mathrm{~W}$ pada tanggal 4 September 2020. Pada kasus 1, biaya pembangkitan listrik adalah Rp 335.855.100, dan emisi 617,7 ton. Untuk kasus ke 3, biaya generatornya adalah Rp251.891.325 dan emisinya 926,68 ton. Pada kasus 5, biaya pembangkitan listrik sebesar Rp 167.935.460, dan emisi 1.235,58 ton. Sedangkan di bawah ini adalah Grafik hubungan antara emisi dengan total biaya produksi seperti yang dapat dilihat pada Gambar 5 sampai dengan Gambar 8. 


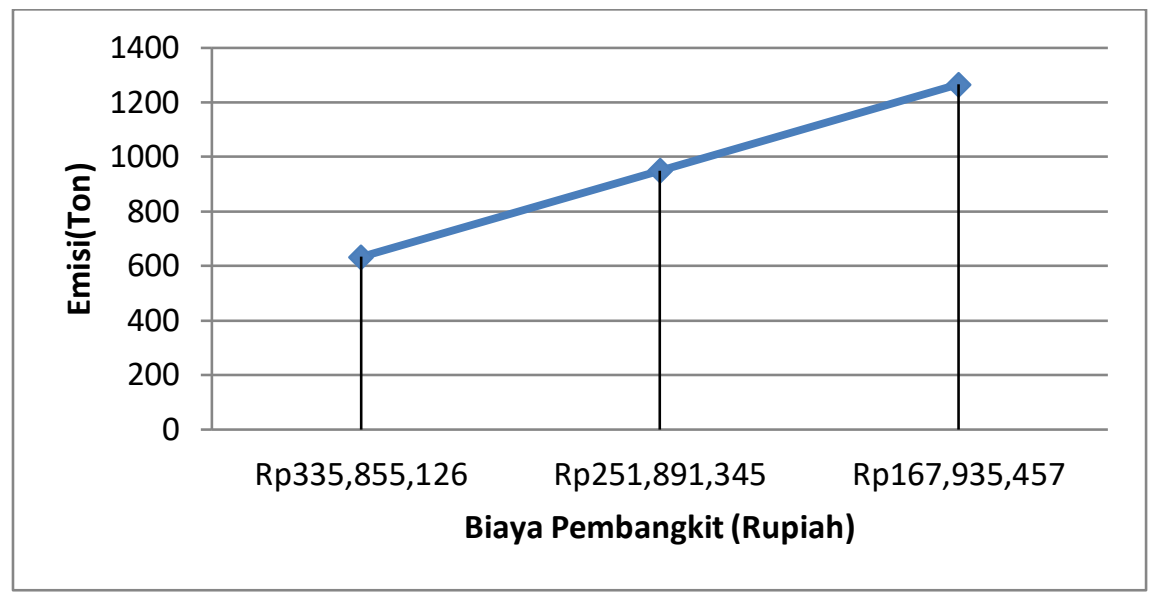

\section{Gambar 5. Grafik hubungan biaya pembangkit dan emisi pada tanggal 1 September 2020}

Pada Gambar 5 diperlihatkan grafik untuk setiap kasus yang akan mempengaruhi biaya pembangkit dan emisi yang ditimbulkan. Apabila nilai pembobotan W1 lebih kecil dan nilai W2 semakin besar maka biaya pembangkit akan semakin besar nilai rupiah (Rp) namun emisi yang dihasilkan semakin kecil, begitu pula sebaliknya. Pada kasus 1 biaya pembangkit sebesar Rp 335.885.126 dan emisi sebesar 633,3 ton. Pada kasus 2 biaya pembangkit sebesar Rp 251.891.345 dan emisi sebesar 950,01 ton. Pada kasus 3 biaya pembangkit sebesar Rp 167.935.457 dan emisi sebesar 1266,7 ton.

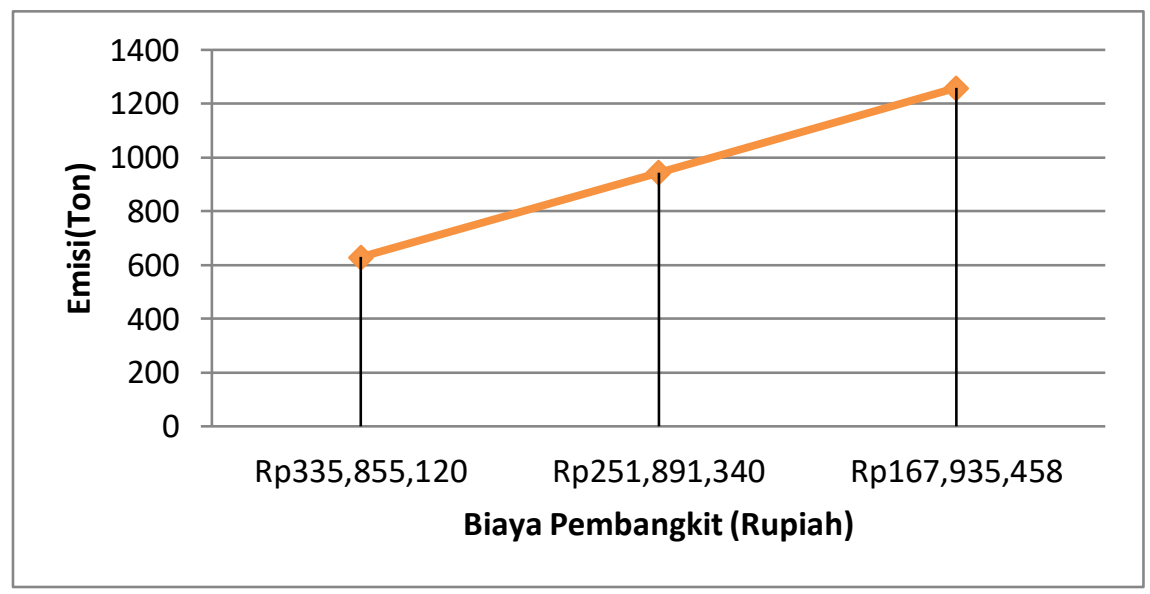

Gambar 6. Grafik hubungan biaya pembangkit dan emisi pada tanggal 2 September 2020

Gambar 6 menunjukkan grafik untuk setiap situasi yang akan mempengaruhi biaya pembangkit listrik dan emisi yang dihasilkan. Jika nilai bobot W1 lebih kecil dan nilai W2 lebih besar, maka biaya pembangkit akan lebih besar dalam nilai rupiah tetapi emisi yang dihasilkan semakin kecil, begitu pula sebaliknya. Pada kasus 1 biaya pembangkitan listrik adalah Rp335.855.120 dan emisinya 629,4 ton. Pada kasus 2 biaya pembangkitan listrik sebesar Rp251.891.340 dan emisi 944,16 ton. Dalam kasus 3 biaya pembangkitan adalah Rp. 167.935 .458 dan emisinya 1258,8 ton. 
Optimasi Ekonomi dan Emisi Pembangkit Listrik di Kalimantan Selatan dan Kalimantan Tengah menggunakan Dragonfly Algoritmh

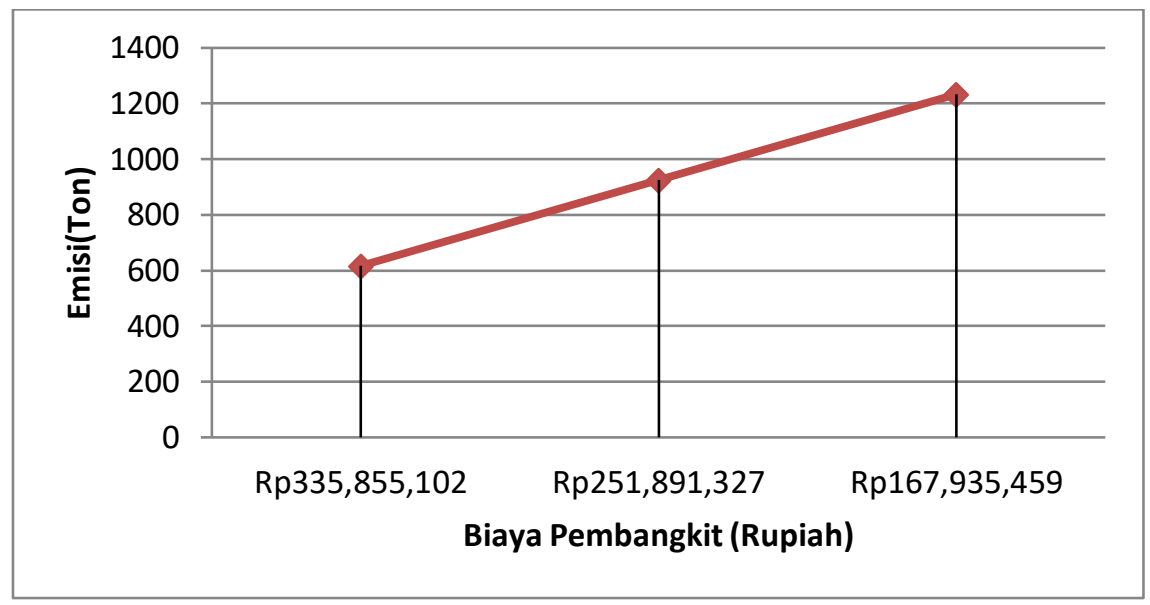

\section{Gambar 7. Grafik hubungan biaya pembangkit dan emisi pada tanggal 3 September 2020}

Gambar 7 diperlihatkan grafik untuk setiap kasus yang akan mempengaruhi biaya pembangkit dan emisi yang dihasilkan. Jika nilai bobot W1 lebih rendah dan nilai W2 lebih besar, maka biaya pembangkitan pembangkit listrik akan lebih tinggi dalam rupiah, tetapi emisi yang dihasilkan akan lebih rendah, dan sebaliknya. Pada kasus 1, biaya generator adalah Rp 335.885102 dan emisi 616,62 ton. Untuk kasus ke 2, biaya generatornya adalah Rp 251.891.327 dan emisinya 924,93 ton. Pada kasus ke 3, biaya generator adalah Rp 167.935.459 dan emisi 1.233,2 ton.

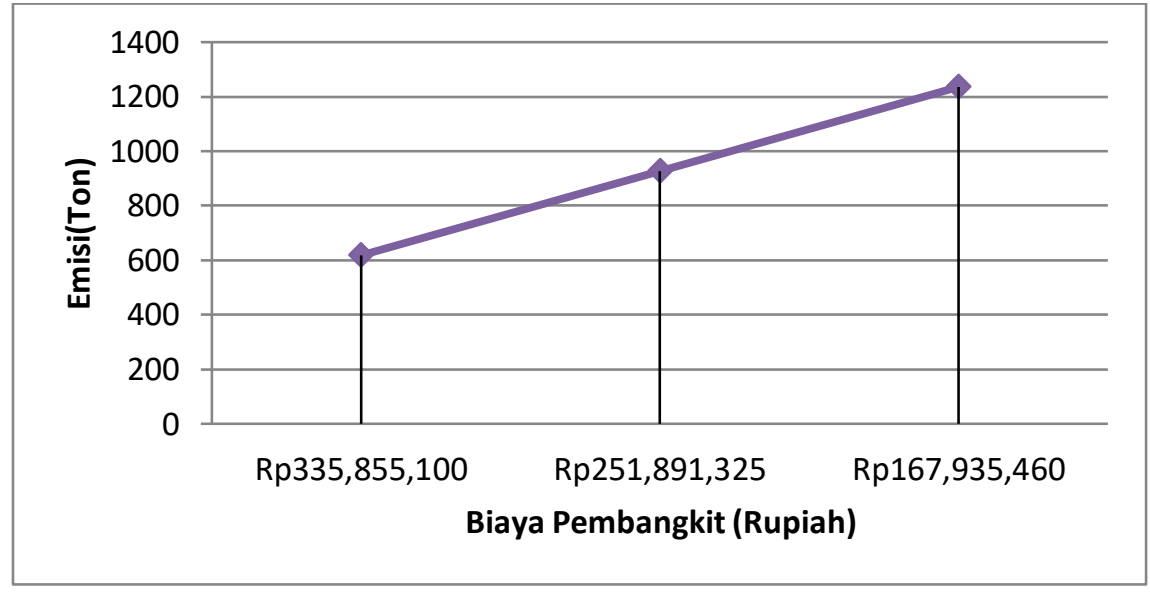

\section{Gambar 8. Grafik hubungan biaya pembangkit dan emisi} pada tanggal 4 September 2020

Gambar 8 menunjukkan grafik untuk setiap situasi yang akan mempengaruhi biaya pembangkit listrik dan emisi yang dihasilkan. Jika nilai bobot W1 lebih kecil dan nilai W2 lebih besar maka nilai Rupiah pembangkit listrik akan semakin besar, namun jumlah emisi yang dihasilkan semakin kecil. Dalam Kasus 1, biaya pembangkitan listrik adalah Rp 335.855.100, dan emisinya 617,7 ton. Pada kasus 3, biaya generator sebesar Rp251.891.325 dan emisi sebesar 926,68 ton. Dalam kasus 5, biaya pembangkitan listrik adalah Rp. 167.935.460, dengan emisi 1.235,58 ton. 


\section{KESIMPULAN}

Berdasarkan hasil yang diperoleh dari simulasi dan analisis optimasi ekonomi dan emisi menggunakan metode Dragonfly Algorithm pada sistem 150 kV Kalimantan Selatan dan Kalimantan Tengah didapatkan rata-rata Biaya Pembangkitan dan Emisi dari tanggal 1 September sampai dengan 4 September 2020 yaitu pada kasus 1 biaya pembangkit sebesar Rp 335.855.120 dan emisi sebesar 628,6 ton. Pada kasus 2 biaya pembangkit sebesar Rp 251.891.340 dan emisi sebesar 943 ton. Pada kasus 3 biaya pembangkit sebesar Rp 167.935.460 dan emisi sebesar 1257,3ton. Dapat ditarik kesimpulan bahwa faktor pembobotan akan mempengaruhi biaya pembangkitan dan emisi yang dihasilkan. Apabila nilai pembobotan W1 lebih kecil dan nilai W2 semakin besar maka biaya pembangkit akan semakin besar nilai rupiah namun emisi yang dihasilkan semakin kecil.

\section{DAFTAR RUJUKAN}

Abdullah, R., Dachyar, M., \& Farizal. (2019). Optimalisasi Pembebanan Pembangkit Pada Sistem 500 kV Jawa Bali Dengan Menggunakan Cuckoo Search Algorithm. Seminar Dan Konferensi Nasional IDEC, (pp. A10.1-A10.7).

Giovanni, I. P. (2016). Dynamic Economic Emission Dispatch Pada Sistem Transmisi JawaBali 500 Kv Berdasarkan RUPTL Tahun 2015-2024 Menggunakan Metode MultiObjective Particle Swarm Optimization (MOPSO). Jurnal Teknik ITS, 5(2),14-20.

Glotić, A., \& Zamuda, A. (2015). Short-term combined economic and emission hydrothermal optimization by surrogate differential evolution. Applied Energy, 141, 42-56.

Jadoun, V. K., Gupta, N., Niazi, K. R., \& Swarnkar, A. (2015). Modulated particle swarm optimization for economic emission dispatch. International Journal of Electrical Power and Energy Systems, 73, 80-88.

Li, J., Lu, J., Yao, L., Cheng, L., \& Qin, H. (2019). Wind-Solar-Hydro power optimal scheduling model based on multiobjective dragonfly algorithm. Energy Procedia, 158, 6217-6224.

Li, L. L., Zhao, X., Tseng, M. L., \& Tan, R. R. (2020). Short-term wind power forecasting based on support vector machine with improved dragonfly algorithm. Journal of Cleaner Production, 242, 118447.

Nguyen, T. T., \& Vo, D. N. (2018). An efficient cuckoo bird inspired meta-heuristic algorithm for short-term combined economic emission hydrothermal scheduling. Ain Shams Engineering Journal, 9(4), 483-497.

PLN. (2015). Perspektif Pengembangan Sistem Ketenagalistrikan Kalimantan Disampaikan Pada : Skema Pembangunan Infrastruktur Ketenagalistrikan ( PIK ). PLN.

Pratama, D. A., Penangsang, O., \& Aryani, N. K. (2017). Economic and Emission Dispatch Pada Sistem Transmisi Jawa Bali 500 kV Berdasarkan RUPTL 2015-2024 
Menggunakan Modified Artificial Bee Colony Algorithm. Jurnal Teknik ITS, 1(2), 7-14. Prayogo, B., Wibowo, R. S. Yani, N. K. A. (2016). Koordinasi Jangka Pendek Pembangkit Hydrothermal menggunakan Firefly algoritm. Jurnal Teknik ITS, 5(2),7-13.

Rahmat, S., Abdullah, A. G., \& Hasbullah. (2014). Koordinasi Hidro Thermal Unit Pembangkitan Jawa-bali menggunakan Metode Dynamic Programming. Electrans, Vol 13 No 2, 444(2), 167-180.

Saadat, H. (2019). Power System Analysis and Design 6th Edition. McGraw-Hill.

Shilaja, C., \& Arunprasath, T. (2019). Internet of medical things-load optimization of power flow based on hybrid enhanced grey wolf optimization and dragonfly algorithm. Future Generation Computer Systems, 98, 319-330.

Sureshkumar, K., \& Ponnusamy, V. (2019). Power flow management in micro grid through renewable energy sources using a hybrid modified dragonfly algorithm with bat search algorithm. Energy, 181, 1166-1178.

Sutanto, H., Haryono, T., \& Setiawan, A. A. (2015). Optimasi Penjadwalan Pada Pembangkit Di Jaringan $500 \mathrm{Kv}$ Jawa-Bali Untuk Mengurangi Emisi Co2 Menggunakan Matpower 5.0. Transmisi, 174), 199-205.

Widyastuti, C., Suyanto, H., \& Febrianini, D. R. (2015). Analisa Interkoneksi Sistem Menggunakan DigSilent. Jurnal IImiah Sutet, 5(1), 24-31. 